\title{
Cellular and Molecular Mechanism of Diabetic Retinopathy
}

\author{
Mohammad Shamsul Ola and Mohd Imtiaz Nawaz \\ Department of Ophthalmology, College of Medicine, King Saud University, Riyadh,
}

KSA

\section{Introduction}

Diabetic retinopathy (DR) is one of the most common complications of diabetes affecting millions of working adults worldwide, in which the retina, a part of the eye becomes progressively damaged, leading to vision loss and blindness. Tremendous efforts have been made to identify biochemical mechanisms which led to the recognition of hyperglycemia, hypertension and dyslipidemia as major risk factors in DR. Consequently, tight glycemic control, blood pressure control and lipid-lowering therapy have all shown proven benefits in reducing the incidence and progression of DR. However, despite tight glycemic control, blood pressure control and lipid-lowering therapy, the number of DR patients keeps growing and therapeutic approaches are limited [Ismail-Beigi F, 2010; Patel A, 2008]. For last several decades, laser photocoagulation and vitrectomy remain as the two conventional approaches for treating sight-threatening conditions such as macular edema and proliferative DR (PDR).

The increased levels of metabolites in diabetic patients and in various animal models of the disease have been shown to induce several unrelated and interrelated biochemical pathways implicated in the progression of the DR. Disturbed level of several metabolites in addition to hyperglycemia and hormonal factors systemically and within diabetic retina change the production pattern of a number of mediators including growth factors, neurotrophic factors, cytokines/chemokines, vasoactive agents, inflammatory molecules, and adhesion molecules resulting in increased blood flow, increased capillary permeability, altered cell turnover (apoptosis) and finally in angiogenesis. In this chapter a major emphasis is given on diabetic induced metabolic changes in the retina which induces a range of molecules and pathways involved early in the pathophysiology of DR which are briefly discussed and those major cascades of events are shown in the schematic diagram as depicted in Fig.1.

\section{Hyperglycemia}

\subsection{Advanced Glycation end products (AGEs)}

AGE's are formed via non-enzymatic condensation reaction between reducing glucoses and amine residues of proteins, lipids or nucleic acids that undergo a series of complex reaction to give irreversible cross linked complex group of compounds termed as AGEs. Some of the 
best chemically characterized AGEs in human are carboxymethyllysine (CML), carboxyethyllysine (CEL), and pentosidine which act a markers for formation and accumulation of AGE in hyperglycemia. CML and other AGEs have been localized to retinal blood vessels of diabetes patients and were found to correlate with the degree of retinopathy suggesting the pathophysiological role of AGE's in diabetes [Stitt AW, 2001]. Increased AGEs formation and accumulation has been found in retinal vessels of diabetic animals, in human serum with type 2 diabetes and in vitreous cavity of people with diabetic retinopathy [Goh SY, 2008; Goldin A, 2006].

Retinal pericytes have been shown to accumulate AGEs during diabetes, implicating pericytes loss which can induce blood-retinal barrier dysfunction [Stitt AW, 2000]. In addition, AGE induces leukocyte adherence that leads to breakdown of blood-retinal barrier via increased leukocyte adhesion to cultured retinal microvascular endothelial cells (ECs) by inducing intracellular cell adhesion molecule-1 (ICAM-1) expression [Moore TC, 2003]. Also retinal vascular endothelial growth factor (VEGF) has been found to induce ICAM-1 expression, thus leading to leukostasis and breakdown of blood-retinal barrier, suggesting AGE-elicited proinflammation, may be modulated by the blockage of VEGF [Joussen AM, 2002; Ishida S, 2003]. AGEs increases monocyte chemoattractant protein-1 (MCP-1) and ICAM-1 expression in microvascular ECs through intracellular reactive oxygen species (ROS) generation, thereby inducing T-cell adhesion to ECs [Yamagishi S, 2007; Inagaki Y, 2003].

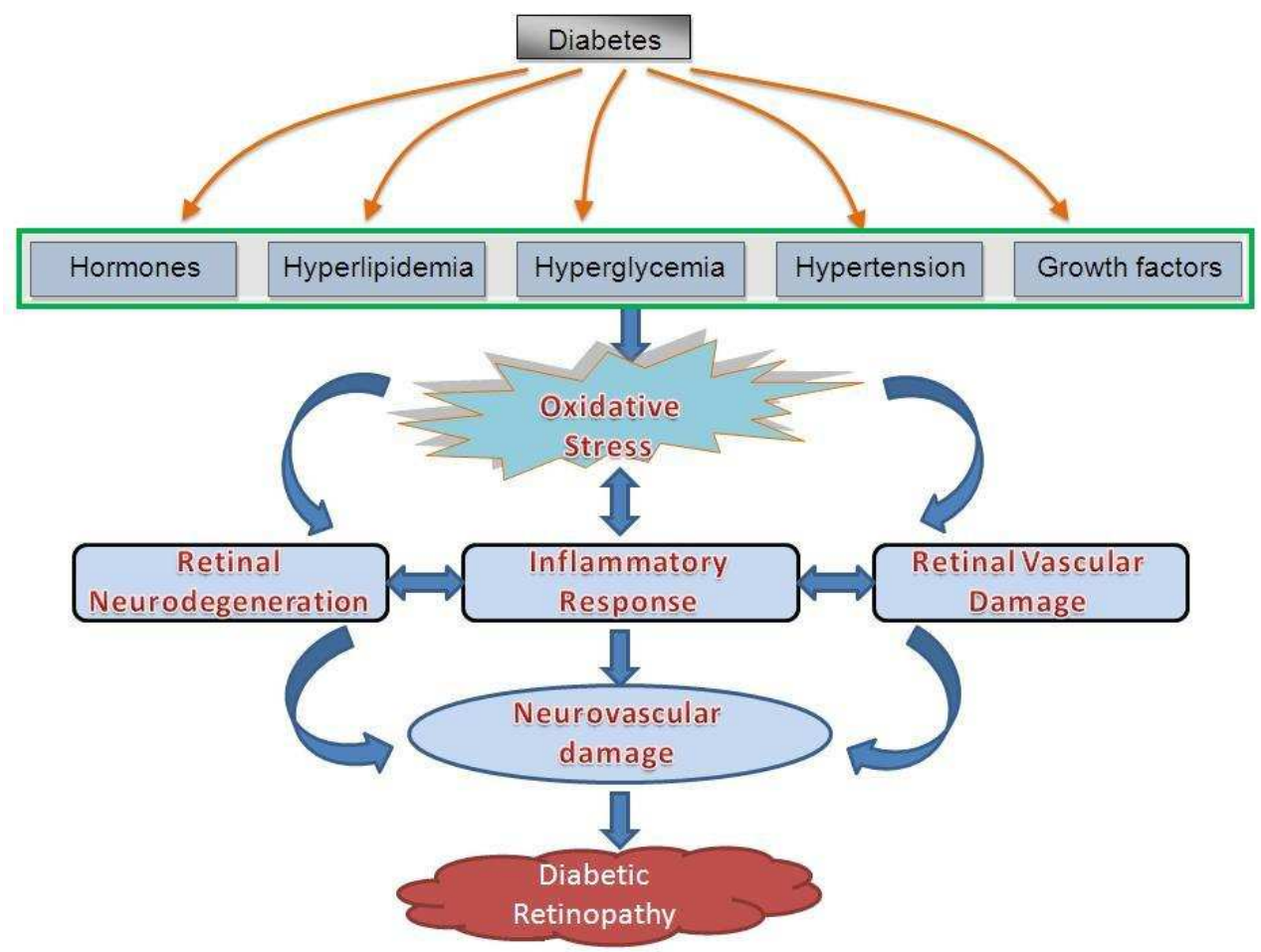

Fig. 1. General features for diabetes induced neurovascular damage in diabetic retinopathy 
AGEs disturb retinal microvascular homeostasis by overproduction of VEGF through the interaction with receptor of advanced glycation end products (RAGE) [Yamagishi S, 2002] and the AGE-RAGE axis could be involved in the development and progression of DR by eliciting pericyte apoptosis and dysfunction [Yamagishi S, 2009]. AGEs induces the activation of nuclear factor-B (NF-kB), with simultaneous increase in the ratio of $\mathrm{Bcl}-2 / \mathrm{Bax}$, and activity of caspase-3, a key enzyme in the execution of apoptosis of pericytes [Yamagishi S, 2002; Denis U, 2002].

Recently, potential therapeutic role of pigment epithelial growth factor (PEDF) as angiostatic, neurotrophic, neuroprotective, antioxidative, and anti-inflammatory properties are widely being discussed and its potential therapeutic property could be exploited as a new option for the treatment of vascular complications in diabetic patients [Yamagishi S, 2008]. Since PEDF levels are decreased in aqueous or vitreous humor in patients with PDR than control, suggesting that loss of PEDF in the eye may contribute to the pathogenesis of PDR [Tombran-Tink J, 2003; Yamagishi S, 2008]. PEDF inhibits the AGE-induced ROS generation and subsequently prevents apoptotic cell death [Yamagishi S, 2008] and also inhibits AGE-induced retinal vascular hyperpermeability in endothelial cells by suppressing nicotinamide adenine dinucleotide phosphate (NADPH)-oxidase mediated ROS generation and subsequently VEGF expression [Sheikpranbabu S, 2010 (a), 2010 (b)]. The work by Yamagishi and his group have shown that injection of AGEs to normal rats increase RAGE and ICAM-1 expression that induced retinal leukostasis and hyperpermeability, however the process was blocked by simultaneous treatment with PEDF that completely inhibited superoxide generation and NF-kB activation in AGE-exposed endothelial cells [Yamagishi S, 2006, 2007]. There is also a significant correlation between the vitreous AGE and VEGF levels and furthermore, both AGEs and VEGF levels (inversely) and PEDF (positively) are associated with the total anti-oxidant status in the vitreous fluid [Yokoi M, 2005, 2007]. All these observations support the concept that PEDF is a potential anti-oxidative agent and anti-inflammatory, that could block the AGE-VEGF axis, thereby may ameliorate the progression of PDR [Yamagishi S, 2009]. Many therapeutic drugs are also being used such as aminoguanidine, pyridoxamine and LR-90 that inhibit glycation reactions and or conversion of early products to AGEs [Abu El-Asrar AM, 2009]. However many such AGE formation inhibitors are still early in clinical trials.

\subsection{Protein Kinase C (PKC)}

Protein Kinase (PKCs) is a family of about 13 isoforms that are widely distributed in various mammalian tissues. In hyperglycemic state, some of the PKC isoforms are produced primarily from enhanced de novo synthesis of diacylglycerol (DAG) from glucose to glycerol 3-phosphate, which act an upstream activator for various isoforms of PKCs, a family of serine/threonine kinases that mediates unique function [Inoguchi T, 1994]. The activities of the classic isoforms (PKC- $\alpha,-\beta 1 / 2$, and PKC- $\delta$ ) are greatly enhanced by DAG and have been linked to vascular dysfunctions and pathogenesis of DR [Geraldes P, 2010]. Hyperglycemia primarily activates the $\beta$ and $\delta$ isoforms of PKC in cultured vascular cells [Koya D, 1997]. Excessive PKC activation underlies microvascular ischaemia, leakage, and angiogenesis in DR. Some of the changes due to PKCs activation include: increase in blood flow, basement membrane thickening, extracellular matrix expansion, vascular permeability, angiogenesis, apoptosis, leukocyte adhesion, and cytokine activation [Aiello LP, 2006; Avignon A, 2006; Das Evcimen N, 2007; Geraldes P, 2010]. 
In the diabetic retina, hyperglycemia not only activates protein kinase $C$ but also mitogenactivated protein kinase (MAPK) to increase the expression of a unknown targets of PKC signaling, like SHP-1 (Src homology-2 domain-containing phosphatase-1), a protein tyrosine phosphatase. This signaling cascade leads to platelet-derived growth factor (PDGF) receptor- $\beta$ dephosphorylation and a reduction in downstream signaling from this receptor, resulting in pericyte apoptosis.[ Geraldes P, 2009].

PKC isoform selective inhibitors are likely new therapeutics, which can delay the onset or stop the progression of diabetic vascular disease. The highly selective PKC $\beta$ activation and its inhibition by ruboxistaurin mesylate have been most extensively studied [Davis MD, 2009]. Clinical studies have shown that ruboxistaurin prevented loss of visual acuity in diabetic patients [Gálvez MI, 2009]. Thus, PKC activation involving several isoforms is likely to be responsible for some of the pathologies in diabetic retinopathy.

\subsection{Polyol pathway}

In diabetes, hyperglycemia activates polyol pathway, where a part of excess glucose are metabolized to sorbitol which is then converted to fructose [Lorenzi M, 2007]. Aldose reductase (AR) is the key and rate limiting enzyme in polyol pathway, and both galactose and glucose are substrates to this enzyme and compete with each other while being reduced to galactitol and sorbitol, respectively. Under physiological conditions glucose is poorly reduced by AR to sorbitol. By contrast, under diabetic condition the intracellular glucose levels are elevated, the polyol pathway of glucose metabolism becomes active and sorbitol is produced [Lorenzi M, 2007; Gabbay KH, 1973; Barba I, 2010]. AR, reduces glucose to sorbitol using NADPH as a cofactor, thereby reducing the NADPH level [B. Lass` egue, 2003] which results in less glutathione and increase in oxidative stress, a major factor in retinal damage [Chung SS, 2003; Brownlee M, 2002]. Retinas from diabetic patients with retinopathy showed high expression of AR protein in nerve fibers, ganglion cells and Müller cells than from nondiabetic individuals [Dagher Z, 2004]. Similarly excess accumulation of sorbitol has been found in various tissues including retina of diabetic animals and also in human retinas from nondiabetic eye donors exposed to high glucose similar to the level in nondiabetic rats retina incubated under identical conditions [Lorenzi M, 2007; Chung SS, 2005]. We also measured rate of polyols formation in ex vivo rat retinas that gave evidence of increased flux through the polyol pathway with increase in the duration of diabetes and with hyperglycemia [Ola MS, 2006]. The use of inhibitor of aldose reductase in many animal models has prevented the early activation of complement in the wall of retinal vessels, apoptosis of vascular pericytes and endothelial cells and the development of acellular capillaries [Dagher Z, 2004].

Accumulated sorbitol within retina may cause osmotic stress and also the byproducts of polyol pathway, fructose-3-phosphtae and 3-deoxyglucosone are powerful glycosylating agents that enter in the formation of AGEs, which are an important factor for the pathogenecity of diabetic retinopathy. Biochemical consequences of polyol pathway activation as studied in the retina of experimentally diabetic rats show an increased nitrotyrosine [Obrosova IG, 2005], lipid peroxidation products and depletion of antioxidant enzymes [Obrosova IG, 2003].Thus, activation of the polyol pathway initiate and multiply several mechanisms of cellular damage by activation and interaction of aldose reductase and other pathogenetic factors such as formation of AGE, activation of oxidative-nitrosative 
stress, PKC pathway and poly(ADP-ribose) polymerase that may further lead to initiation of inflammation and growth factor imbalances [Obrosova IG, 2011]. The use of fidarestat, an inhibitor of aldose reductase counteracts diabetes-associated retinal oxidative-nitrosative stress and poly (ADP-ribose) polymerase formation [Obrosova IG, 2005] supporting an important role for aldose reductase in diabetes and rationale for the development of aldose reductase inhibitors for counteraction of polyol pathway [Drel VR, 2008].

\subsection{Hexosamine pathway}

The hexosamine biosynthesis pathway is another hyperglycemic induced pathway which has been implicated in diabetic pathogenesis [Giacco F, 2010]. Increased expression of an enzyme called GFAT (glutamine: fructose-6 phosphate amidotransferase) causes the diversion of some of glycolytic metabolites such as fructose- 6 phosphate to the hexosamine pathway producing UDP (uridine diphosphate)-N-acetylglucosamine which is a substrate used for the post-translational modification of intracellular factors including transcription factors [Nerlich AG, 1998; Brownlee M, 2005]. Du and coworkers have shown the role of hyperglycemia in activation of hexosamine pathway that increases the expression of plasminogen activator inhibitor-1 (PAI-1) and transforming growth factor- $\beta 1$ (TGF- $\beta 1$ ), which are deleterious for diabetic blood vessels and may contribute to the pathogenesis of diabetic complications [Du XL, 2000]. Hyperglycaemia results in increased glucosamines may cause insulin resistance in skeletal muscle and adipocytes and heamoglobin-A1c (HbA1c) which significantly correlates with basal GFAT activity in Type 2 diabetes [YkiJärvinen H, 1996; Buse MG, 2006]. Few studies suggest that hexosamine biosynthetic pathway may cause retinal neurodegeneration via either affecting the neuroprotective effect of insulin or through the induction of apoptosis possibly by altered glycosylation of proteins [Nakamura M, 2001].

The ability of benfotiamine, a lipid soluble thiamine, to inhibit simultaneously the hexosamine pathway along with AGE formation and PKC pathways might be clinically useful in preventing the development and progression of diabetic pathogenesis arising due to hyperglycemia induced vascular damage [Hammes HP, 2003].

\subsubsection{Poly (ADP-ribose) Polymerase (PARP)}

Poly (ADP-ribose) Polymerase (PARP) is a nuclear enzyme residing as an inactive form which gets activated after the cell receives the DNA damaging signals. Increased intracellular glucose generates increased ROS in the mitochondria, which induces DNA strand breaks, thereby activating PARP. Once activated, PARP depletes its substrate, NAD ${ }^{+}$ molecule, by breaking into nicotinic acid and ADP-ribose, slowing the rate of glycolysis and mitochondrial function. By inhibiting mitochondrial superoxide or ROS production with either MnSOD or UCP-1, prevented both modification of glyceraldehyde 3-phosphate dehydrogenase (GAPDH) by ADP-ribose and reduction of its activity by hyperglycemia [Du $X, 2003]$. PARP was found to decrease the GAPDH activity, activate the polyol and PKC pathways, increases intracellular AGE formation and activates hexosamine pathway flux which trigger the production of reactive oxygen and nitrogen species, playing a role in the pathogenesis of endothelial dysfunction and diabetic complications. PARP also potentiates NF- $\mathrm{kB}$ activation resulting in increase of the expression of NF- $\mathrm{kB}$ dependent genes such as ICAM-1, MCP-1 and TNF- $\alpha$ with increase in leukostasis and producing greater oxidative 
stress. PARP inhibition suppresses NF-kB activation and expression of adhesion molecule in cultured endothelial cells under high glucose [Zheng L, 2004]. More recently, Drel et al., demonstrated an increase in PARP activity in streptozotocin induced diabetic rats and PARP inhibitors reduced retinal oxidative-nitrosative stress, glial activation, and cell death in palmitate exposed pericytes and endothelial cells [Drel VR, 2009].

\subsubsection{Peroxisome Proliferator Activator Receptor-y (PPAR- Y)}

PPAR- $\gamma$ is a member of ligand-activated nuclear receptor superfamily, which plays an important role in carbohydrate metabolism, angiogenesis and inflammation [MalchiodiAlbedi F, 2008; Yanagi Y, 2008]. PPAR-ץ is highly expressed in retinal cells, macropahges and other cell types that influence inflammation such as microglial cells, a resident macrophage present both in brain and retina, indicating that PPAR- $\gamma$ might modulate diabetes induced activation of these cells involved in inflammation and neurodegeneration [Bernardo A, 2006]. The recent work by Tawfik and group has shown the down regulation of PPAR-y expression in oxygen induced retinopathy in an experimental model of diabetes [Tawfik A, 2009]. In streptozotocin induced diabetic mice deficient in PPAR- $\gamma$ expression had increased leukostasis and leakage compared to wild type control mice, indicating that endogeneous PPAR- $\gamma$ and its activation by specific ligands is critical for inhibiting leukostasis and leakage in diabetic mice [Muranaka K, 2006]. PPAR-ץ also acts as agonist by inhibiting the VEGF-stimulated proliferation, migration and tube formation in PPAR- $\gamma$ expressing retinal endothelial cells [Murata T, 2000]. In diabetic patients, PPAR-ץ agonists have been shown to reduce several markers of inflammation such as serum levels of creactive protein, interleukin-6 (IL-6), monocyte chemoattractant protein (MCP-1) and matrix metallo ptoteinase 9 (MMP-9) [Agarwal R, 2006]. In-vitro studies showed that PPAR- $\gamma$ agonists suppress activated NF- $\mathrm{\kappa B}$ and decrease ROS generation in blood mononuclear cells [Aljada A, 2001]. Many such studies suggest the use of PPAR-ץ agonists in the treatment of diabetic retinopathy.

\subsection{Oxidative stress}

The retina is highly metabolic active tissue, making it susceptible to increased oxidative stress. Diabetes disturbs the cellular homeostasis in the normal retina by metabolic dysregulation of glucose, lipids, amino acids and other metabolites which causes oxidative stress, implicating in the in the pathogenesis of diabetic retinopathy.

Oxidative stress is believed to play a pivotal role in the development of diabetic retinopathy by damaging retinal cells [Sato $H, 2005$ ]. However, the potential sources of ROS, is still unclear although a number of studies showed that high glucose and the diabetic state stimulate flux through the glycolytic pathway, increases cytosolic NADH, tissue lactate-topyruvate ratios, and tricarboxylic acid cycle flux thereby producing excess level of ROS [Madsen-Bouterse SA, 2008; Ido Y, 1997; Obrosova IG, 2001]. ROS can be produced by activation of AGE, aldose reductase, hexosamine and PKC pathways induced by hyperglycemia, altered lipoprotein metabolism, excess level of excitatory amino acids and altered growth factor or cytokines/chemokines activities [Ola MS, 2006; Kanwar M, 2009]. Oxidative stress creates a vicious cycle of damage to macromolecules by amplifying the production of more ROS and activates other metabolic pathways that are detrimental to the 
development of diabetic retinopathy. However, it is still unclear whether oxidative stress has a primary role in the pathogenesis of diabetic complication, occurs at an early stage in diabetes or it is a consequence of the tissue damage. Other sources of oxidative stress are the activation of NADPH oxidase which may increase superoxide, induction of xanthine oxidase, decreased tissue concentration of endogenous antioxidants such as glutathione and impaired activities of antioxidant defense enzymes such as superoxide dismutase (SOD) and catalase [Sonta T, 2004; Al-Shabrawey M, 2008; Madsen-Bouterse SA, 2008].

To develop novel therapeutic strategies that specifically target ROS is actually desired for patients with PDR. The use of PEDF as a therapeutic option which has a anti-oxidative, antiangiogenic, neuroprotective and anti-inflammatory properties could be used to block pathways that leads the production of ROS [Yamagishi S, 2011]. Vitamin E has a protective role against lipid peroxidation, whereas its effects on protein and DNA oxidation are less pronounced [Pazdro R, 2010].

\section{Hyperlipidaemia}

Increased level of plasma lipid has been found to be involved in the pathogenesis of microvascular disease [Ansquer JC, 2009]. High content of lipid in diabetic patients increases the risk of diabetic retinopathy and particularly diabetic macular edema [van Leiden HA, 2002]. Still it is unclear how altered lipids level affect the onset and progression of diabetic retinopathy, may be through alterations in metabolic processes that alters concentration of serum compounds such as ketone bodies, acylcarnitine and oxidized fatty acids [Adibhatla RM, 2007]. There is a growing body of evidence suggest that serum lipid/fatty acid composition, concentration and tissue distribution contribute to the development and severity of this disease [Berry EM, 1997; Kowluru RA, 2007; Nagao K, 2008]. The contribution of lipids/fatty acid may be particularly important in the context of type I diabetes, where hypoglycemia and hyperglycemia co-exist.

The major sources of fatty acids/lipids are from the modern diets (Western in particular) that have a high fat content [Hu FB, 2001]. Not only these diets have high caloric content, but also have high levels of saturated and trans-fatty acids (SFA), rather than the generally beneficial cis-monounsaturated or polyunsaturated fatty acids. Thus understanding the details of metabolic response of diabetic mice to Western diets may aid in understanding, how dietary lipid/fatty acids contribute to the complication of diabetes. The sensitivity of retina to fatty acid is well documented and thus understanding how diet affects the levels of these key metabolites will provide important new information about their role in DR [Giovanni JP, 2005; Adibhatla RM, 2007]. Very long chain unsaturated fatty acids such as docosahexaenoic acids (DHA) are essential for retinal development and function, and free fatty acids in this class have been shown to be protective against age related macular degeneration in a mouse model [Connor KM, 2007]. Diet high in SFA and deficient in the precursors of important retinal fatty acids may adversely affect retinal function or increase the pathology. In the context of type I diabetes, a high fat diet may also increase oxidative stress [Kowluru RA, 2007] and contributes to the inflammatory response [Fox TE, 2006] as well as alter metabolism and metabolite pools in the retina [Antonetti DA, 2006].

ETDR (early treatment of diabetic retinopathy) study demonstrated that elevated serum lipid levels are associated with an increased risk of retinal hard exudates, accompanying 
diabetic macular edema with an increased risk of visual impairment. The presence of hard exudates in diabetic retinopathy patients has been shown to be associated with increased serum cholesterol levels [Li J, 2009; Rodriguez-Fontal M, 2009]. The therapeutic use of lipid lowering drugs such as fibrates and cholesterol lowering drug, statins, may have great potential in the treatment of diabetic retinopathy.

\section{Renin Angiotensin System (RAS)}

Hypertension has been identified as a major risk factor of microvascular complications leading to small vessel dysfunction, manifesting the state of diabetic retinopathy. In patients with diabetic retinopathy, tight control of blood pressure delays the progression of the disease and growing evidence suggests that RAS plays an important role in the regulation of blood pressure. The RAS is an enzymatic cascade in which angiotensinogen is the precursor of the angiotensin peptides. The cascade begins with the conversion of the inactive form of renin, prorenin, to active renin [Satofuka S, 2009]. Renin converts angiotensinogen to angiotensin-1 (Ang I) which is further cleaved by angiotensin converting enzyme (ACE) to angiotensin-II (Ang II). Ang II is the main effector peptide of the RAS, acting primarily on two receptors, the angiotensin type I (AT-1) and angiotensin type 2 (AT22). Ang II is known to cause systemic and, local blood pressure via its constrictor effect by upregulation of angiotensin II type 1 receptor.

A number of investigators studied components of retinal RAS (Ang I, Ang II, renin, ACE, AT-1, AT-2) in the retina and increased levels of prorenin, rennin and angiotensin II have been reported in the vitreous of patients with PDR and diabetic macular edema (DME) suggesting the involvement of RAS in pathogenesis of diabetic retinopathy [Noma H, 2009; Nagai N, 2005]. Ang II is also a growth factor, promoting differentiation, apoptosis and the deposition of extracellular matrix [Otani A, 2001; Suzuki Y, 2003]. Ang II potentiates deleterious effect of AGEs by inducing RAGE expression in hypertensive eye and can be blocked by telmisartan, an inhibitor of ACE, indicating a link between AGE-RAGE and the RAS which may be involved in the pathogenesis of diabetic retinopathy.

Angiotensin induce cell growth, proliferation and the deposition of extracellular matrix proteins via stimulation of growth factors such as transforming growth factor (TGF- $\beta$ ), platelet-derived growth factor (PDGF), vascular endothelial growth factor (VEGF), and connective tissue growth factor (CTGF) [Ruperez M, 2003]. There is evidence that the AT-2 receptor also influences pathological angiogenesis in rats with oxygen induced retinopathy and blockade of the AT-2 receptor was shown to reduce retinal angiogenesis and expression of VEGF, VEGFR-2 and angiopoietin-2. In diabetic rats both AT-1 and AT-2 receptor blockade attenuate the rise in retinal VEGF expression [Zhang X, 2004]. Blockade of the RAS at the level of ACE inhibition or angiotensin reduces the rise in retinal VEGF and VEGFR-2 that occurs in diabetic rats and transgenic rats with OIR and attenuates vascular pathology including vascular leakage, proliferation of endothelial cells, angiogenesis [Kim JH, 2009], leukostasis [Chen P, 2006] and inflammation [Egami K, 2003]. Recently, Nagai et al. studied the involvement of RAS and NF-kB pathway in diabetic induced retinal inflammation by upregulation of ICAM-1, MCP-1 and VEGF which are attenuated by AT-1 receptor blocker [Nagai N, 2007]. Therefore, RAS plays an important role in the pathogenesis of diabetic retinopathy and this has led a major interest in RAS inhibitors to prevent retinopathy. 


\section{Hormones}

Several hormones such as insulin, aldosterone, adrenomesdulin, growth hormone (GH) and endothelin have been found to be implicated in diabetic retinopathy [Wilkinson-Berka JL, 2008]. Insulin stimulates anabolic functions and prevents the breakdown of skeletal muscle tissue. In diabetes, the loss of insulin signaling profoundly alters carbohydrate, lipids, amino acids and protein metabolism in a range of tissues including retina, altering nutrients pool and resulting in metabolic dysregulation that ultimately induces tissue damage. Also, the loss of insulin action in diabetic patients causes muscle loss [Serrarbassa PD, 2008]. Numerous studies towards understanding whether the role of insulin concise to its effect on blood level only or extend its role in maintaining retinal homoeostasis reveals the neurotrophic action of insulin [Meyer-Franke A, 1995] pointing to the possibilities that exogenous insulin have a role in the treatment of DR via its neurotrophic actions [Reiter CE, 2006]. Few studies also describe the role of insulin in inflammatory processes [Fort PE, 2009]. Data and research from the Diabetes Control and Complications Trial (DCCT, Diabetes, 1995), as a study by Barber et al. demonsonstrated that administration of exogenous insulin reduces the risk and progression of retinopathy [Barber AJ, 1998]. Use of several implantable hydrogels with degradable and thermoresponsive properties are widely being tested for slow and sustained local release of insulin to the retina [Misra GP, 2009; Kang Derwent JJ, 2008]. However further investigations of both efficiency and potency of such locally administered insulin needs a more indepth studies and research.

Growth factors $(\mathrm{GH})$ have been recently found in vitreous fluid of human, in which they regulate retinal function and provide markers of ocular dysfunction. The presence of $\mathrm{GH}$ in the human vitreous suggests that vitreous GH may be involved in the pathogenesis of various forms of ocular diseases including PDR [Harvey S, 2009; Malhotra C, 2010]. It has been shown that the low $\mathrm{GH}$ concentrations in the vitreous of diabetic patients may correlate with retinal neurodegeneration making it a marker to follow progression of diabetes [Ziaei M, 2009]. Systemic inhibition of GH or insulin like growth factor (IGF-1) or both, may have therapeutic potential in preventing some forms of retinopathy [Smith LE, 1997]. Thus growth hormone may play a major role in the progression of diabetic retinopathy in combination with IGF-I and VEGF.

\section{Inflammation and diabetic retinopathy}

Many of the molecular and functional changes that are characteristic of inflammation have been detected in retinas from diabetic animals or humans, and in retinal cells under diabetic conditions which support the potential role of proinflammatory cytokines, chemokines and other inflammatory markers in DR [Adamis AP, 2008]. Joussen et al, have shown that CD18-/- and ICAM-1-/- mice have significantly fewer adherent leukocytes which is associated with fewer damaged endothelial cells and lesser vascular leakage [Joussen AM, 2004]. Leukostasis is a condition that is characterized by abnormal intravascular leukocyte aggregation and clumping which play a major role in inflammatory process in patient with DR [Tamura H, 2005; Tadayoni R, 2003]. Leukostatsis has been shown to be increased in retinas of diabetic animals and contributes to the capillary nonperfusion and also suggests that increased leukocyte-endothelial cell adhesion and retinal leukostasis as 
an early event associated with areas of vascular non-perfusion that leads to the development of diabetic retinopathy [Chibber R, 2007; Kern TS, 2007; Joussen AM, 2004; Ishida S, 2003].

The role of proinflammatory transcription factors that are responsible for inflammatory process includes the production of proinflammatory mediators such as NF- $\mathrm{kB}$, specificity protein 1 (Sp1), activator protein 1 (AP-1), PPARs and other members of the nuclear receptor superfamily [Rahman I, 2002; Yang SR, 2006 ]. A variety of diabetes induced metabolic factors including AGEs, PKC, polyols and oxidative stress may activate NF- $\mathrm{kB}$ and thereby release proinflammatory cytokines, chemokines and other inflammatory mediator proteins [Gao X, 2008 (a)].

Proinflammatory cytokines such as Interleukin-1 $\beta$ (IL-1 $\beta$ ), Tumor necrosis Factor- $\alpha$ (TNF- $\alpha)$ and IL-6 were found to be significantly higher in vitreous of PDR than in control patient and their role in retinal pathogenesis leading to PDR have been characterized. Increased levels of IL-1 $\beta$, is detected in vitreous fluid of the patients with PDR [Demircan N, 2006; Sato T, 2009] and in the retina from diabetic rats [Vincent JA, 2007] suggesting that IL-1 $\beta$ might have an important role in the pathogenesis of diabetic retinopathy. Using the IL-1 receptor antagonist (IL-1Ra) which causes a blockade of IL-1 activity reduces tissue inflammation in the type 2 diabetic rat [Ehses JA, 2009]. TNF-a is a potent proinflammatory cytokine that is involved in various immunologic and pathologic reactions including upregulation of proliferation, differentiation and cell death [Gao X, 2007, 2008 (b)]. The data provides the evidence of the activation of the local synthesis of TNF-a along with other cytokines such as Endothelin-1 (ET-1) and IL-6 in PDR [Adamiec-Mroczek J, 2010]. Furthermore, the role of several cell adhesion molecules such as soluble vascular cell adhesion protein-1 (sVCAM) and soluble ICAM have been shown to correlate with the vitreous VCAM-1 and TNF- $a$ concentration [Adamiec-Mroczek J, 2009; Adamiec-Mroczek J, 2008]. In addition, increased level of TNF-a in diabetic plasma has been shown to induce leukocyte cell adhesion [BenMahmud BM, 2004]. The role TNFa is critical for the later complications and progression of blood retinal barrier (BRB) breakdown. In diabetes induced TNF-a knockout mice the BRB breakdown was completely suppressed showing that TNFa is essential for progression BRB breakdown and would be a good therapeutic target to prevent BRB breakdown, retinal leukostasis, and apoptosis associated with DR [Huang H, 2011]. Increased level of IL-6 is detected in vitreous fluid of the patients with PDR and DME [Noma H, 2009; Murugeswari $P, 2008]$. Serum level of IL-6 in patients with both type 1 and type 2 diabetes were also found to be increased [Myśliwiec M, 2008; Bertoni AG, 2010]. Levels of soluble IL-6 receptor in the vitreous and serum of patients with PDR was found to be significantly higher than control [Kawashima M, 2007]. Increased level of IL-6 was found to be related to retinal vascular permeability and the severity of DME [Noma H, 2009; Noma H, 2010]. Up-regulation of IL-6 increase leukocyte-endothelial interaction which contributes to breakdown of $\mathrm{BRB}$ in diabetes [Adamis AP, 2008].

Chemokines such as MCP-1, IP-10, IL-8 and stromal derived factor-1 (SDF-1) have been also found to play a potential role in pathogenesis of diabetic retinopathy [Murugeswari P, 2008; Yoshimura T, 2009]. MCP-1 which is a strong activator of macrophages and monocytes, have been shown to be involved in the pathogenesis of DR where vitreous MCP-1 levels are 
increased in PDR compared with those in controls [Maier R, 2008; Hernández C, 2005]. The angiogenic effect of MCP-1 was completely inhibited by a VEGF inhibitor, suggesting that MCP-1 induced angiogenesis is mediated through pathways involving VEGF [Hong $\mathrm{KH}$, 2004].The increased MCP-1 expression contributes to the development of neovascularization and fibrosis in proliferative vitreoretinal disorders [Yoshida S, 2003]. Abu El-Asrar and others have found increased levels of IP-10 in the vitreous humor samples from eyes with PVR and PDR patients [Abu El-Asrar AM, 2006;Maier R, 2008] and IP-10 expression under both in vitro and in vivo conditions has been shown to be induced by VEGF, indicating a potent angiogenesis factor in PDR [Maier R, 2008]. VEGF induced augmentation of IP-10 expression is a major mechanism underlying its proinflammatory function. In age-related macular degeneration, IP-10 is also marked as early biomarkers to understand the regulation and neovascular response [Mo FM, 2010]. The work by Liu shows that diabetic tears exhibited elevated levels of pro-angiogenic cytokines such as IP-10 and MCP-1 than anti-angiogenic cytokines [Liu J, 2010]. IL-8 is angiogenic and inflammatory mediator which is elevated in vitreous of patients with PDR in comparison to control subjects [Murugeswari P, 2008; Petrovic MG, 2007]. It has been shown that IL-8 is produced by endothelial and glial cells in the retina with ischemic angiogenesis [Yoshida A, 1998] where it could act as a marker of ischaemic inflammatory reaction, and play a role in deteriorating visual acuity by DR progression [Petrovič MG, 2010].

In humans, vitreous SDF-1 concentration increases as proliferative diabetic retinopathy progresses [Butler JM, 2005; Sonmez K, 2008]. Abu El-Asrar and coworkers have shown that expression of SDF-1 and its receoptor CXCR4 in PDR epiretinal membranes [Abu El-Asrar AM, 2006; Abu El-Asrar AM, 2011]. SDF-1 is upregulated in ischemic tissue establishing an SDF-1 gradient favoring recruitment of EPCs from peripheral blood to sites of ischemia, thereby accelerating neovascularization. The intravitreal injection of bevacizumab and triamcinolone in patient with PDR potentially diminishes the level of SDF-1 that in turn eliminate diffuse macular edema, and cause regression of active aberrant neovascularization (NV) suggesting the possible role of SDF-1 in the pathogenesis of the adverse visual consequences of DR [Arimura N, 2009; Brooks HL Jr, 2004].

The role of various growth factors such as epidermal growth factor (EGF), VEGF, basic FGF, granulocyte colony-stimulating factor (G-CSF) and granulocyte-macrophage colonystimulating factor (GM-CSF) in the retinal pathogenesis have been evaluated. Schallenberg and his group have shown that the hematopoietic cytokine, GM-CSF and its receptor are expressed within rat and human retina where GM-CSF reduced apoptosis and protected injured retinal ganglion cells by activating the ERK1/2 pathway [Schallenberg M, 2009].

\section{Neuronal damage in diabetic retinopathy}

\subsection{Neurodegeneration}

A pathogenic mechanism of nerve damage in diabetic retinopathy begins shortly after the onset of diabetes. Several clinical tools such as multifocal electroretinography (ERG), flash ERG, contrast sensitivity, color vision, and short-wavelength automated perimetry, all detect neuronal dysfunction at early stages of diabetes [Han Y, 2004; Bearse MA, 2004; Fletcher EL, 2007]. Occurrence of many functional changes in the retina can be identified 
before the development of vascular pathology, suggesting that they result from a direct effect of diabetes on the neural retina [Lieth E, 2004]. Diabetic mice develop capillary lesion that are characteristic of the early stages of DR and cause pathologic progression resulting due to neuronal loss or upregulation of glial fibrillary acidic protein (GFAP) in retinal glial cells [Feit-Leichman RA, 2005]. Van Dijk and his group has shown the gradual and selective thinning of mean ganglion cell/inner plexiform retinal layer in type 1 diabetic patients [van Dijk HW, 2009] which further supports the concept that early DR includes a neurodegenerative sign [van Dijk HW, 2010; Peng PH, 2009]. Retinal glial cells that play important roles in maintaining the normal function of the retina, after the onset of diabetes the normal function of these cells are altered and compromised. They are known to become gliotic displaying altered potassium siphoning, GABA uptake, glutamate excitoxicity and are also known to express several modulators of angiogenic factors. In addition to metabolic stress, there are many growth factors involved in process of neuronal death in DR suggesting further investigation into the mechanism of neurodegenaration [Whitmire $\mathrm{W}$, 2011].

\subsection{Apoptosis}

Even before the emergence of the concept of programmed cell death (PCD)/apoptosis in diabetes, studies have identified a pyknotic bodies in histological sections of the retina of people with diabetes [Bloodworth JM Jr, 1962; Wolter JR, 1962]. Diabetes causes chronic loss of inner retinal neurons by increasing the frequency of apoptosis as studied in streptozotocin-induced diabetic mice [Martin PM, 2004]. Many findings suggest that the visual loss associated with DR could be associated not only to an early phase of photoreceptor loss but also to later microangiopathy [Park SH, 2003], so both retinal neurodegeneration and retinal microangiopathy should be considered as sign and onset of DR [Ning X, 2004]. Caspases, the enzymes involved in apoptosis are also elevated in retinas of diabetic rats thus making them as markers for apoptosis [Mohr S, 2002]. The role of proinflammatory cytokine (IL-1 $\beta$ ) and caspase- 1 in diabetes-induced mice have shown that caspase-1/IL-1 $\beta$ signaling pathways play an important role in degeneration of retinal capillaries [Vincent JA, 2007] and its inhibition might represent a new strategy to inhibit capillary degeneration in diabetic retinopathy [Mohr S, 2008]. The increased expression of apoptotic mediators, Bcl-2 in the vascular endothelium inhibits the diabetes-induced degeneration of retinal capillaries and superoxide generation [Kern TS, 2010; Susnow N, 2009].

Several studies also demonstrate that the expression of Bax (Bcl-2 associate $\mathrm{X}$ protein), proapoptotic protein is associated with degenerative diseases and are increased in retinas of diabetic rats, confirming the increase in apoptosis within the inner retina as a component of DR [Podesta F, 2000]. Involvement of TNF- $a$ and AGE, in retinal pericyte apoptosis through activation of the pro-apoptotic transcription factor Forkhead box O1 (FOXO1) establishes the possible mechanism of apoptosis in DR [Alikhani M, 2010].

\subsection{Glutamate excitotoxicity}

Glutamate is the excitatory neurotransmitter in the retina, but it is neurotoxic when present in excessive amounts. Crucial role in the disruption of glutamate homeostasis in diabetic retina is due to decrease in the ability of Müller cells to remove the excess amount 
of glutamate from the extracellular space causing excitotoxicity leading to neurodegeneration [Li Q, 2002; Diederen RM, 2006]. Extracellular glutamate is transported into Müller cells by glutamate transporters (GLAST) and amidated by glutamine synthetase (GS) to the non-toxic amino acid, glutamine. Yu XH and coworkers have shown a linear correlation between time-dependent reduction in GS expression and the time course of diabetic retinopathy, making GS as a possible biomarker for evaluating the severity of diabetic retinopathy [Yu XH, 2009]. At postsynaptic neurons, two major classes of receptors referred to as amino-3-hydroxy-5-methyl-4-isoxazolepropionic acid (AMPA) receptors and N-methyl-D-aspartate (NMDA) are activated by excess glutamate. The major causes for cell death following activation of NMDA receptors are the influx of calcium and sodium into cells, the generation of free radicals linked to the formation of AGEs and/or advanced lipoxidation endproducts (ALEs) as well as defects in the mitochondrial respiratory chain. Thus, glutamate may play an important role in the progression of disease and treatment by glutamate inhibitors may decrease neurotoxicity [Ola MS, 2011].

\subsection{Role of neurotrophic factors}

Neurotrophic factors play important roles in regulating growth, maintenance and survival of neurons [Mattson MP, 2004]. The role of brain derived neurotrophic factors (BDNF) in metabolism is supported by studies on BDNF-deficient mice which develop obesity and hyperphagia in early adulthood [Kernie SG, 2000] whereas, when it administered to normal mice or rats, it has no effect on blood glucose levels, indicating that BDNF exerts its effects by enhancing insulin sensitivity [Ono M, 1997] and activates several signaling pathways including phosphatidylinositol-3 kinase/Akt [Cotman CW, 2005]. Plasma levels of BDNF were decreased in humans with type 2 diabetes accompany impaired glucose metabolism [Krabbe KS, 2007] and act like a biomarkers of insulin resistance [Fujinami A, 2008]. Recently to understand the mechanism of action of BDNF under normal and hypoxic condition in Müller cells, BDNF treated cells increased glutamate uptake and also up regulated glutamine synthetase (GS) during hypoxia which may underlie neuroprotective effects of BDNF [Min D, 2011]. The therapeutic merit of BDNF was also evaluated by injecting it in diabetic mice, which not only ameliorated glucose metabolism [Yamanaka M, 2008 (a)] but also prevented the development of diabetes in pre-diabetic mice [Yamanaka M, 2008 (b)]. Treatment with ciliary neurotrophic factor (CNTF) in combination with brain derived neurotrophic factor (BDNF) is shown to rescue photoreceptors in retinal explants, conveying its neuroprotective effects [Azadi S, 2007].

Several studies have shown an elevated level of Nerve Growth Factor (NGF), another potent neurotrophic factor, which contributes to neurogenic inflammation [Barhwal K, 2008]. NGF level was significantly elevated in the PDR samples as compared to controls, indicating that NGF might be a potent angiogenic factor in the pathogenesis of PDR [Chalam KV, 2003].

Another neurotrophic includes Basic Fibroblast Growth Factor (bFGF), which is important for survival and maturation of both glial cells and neurons and play an important role in regeneration after neural injury [Bikfalvi A, 1997; Molteni R, 2001]. Study found an increase in bFGF concentration in vitreous samples from patients with PDR [Sivalingam A, 1990] revealing that bFGF is a potent angiogenic factor playing an important role in the 
pathogenesis of neovascularization in DR [Wong CG, 2001]. Studies also suggest that bFGF have a therapeutic value for diabetic neuropathy when injected with cross-linked gelatin hydrogel in streptozotocin-induced diabetic rats [Nakae M, 2006].

Glial cell line-derived neurotrophic factor (GDNF) is a member of the transforming growth factor- $\beta$ (TGF- $\beta$ )-related neurotrophic factor family. GDNF promotes photoreceptor survival during retinal degeneration mediated by interaction of the neurotrophic factors via receptors in Müller glial cells that in turn release secondary factors that act directly to rescue photoreceptors [Harada C, 2003].

\section{Conclusions}

As described in this chapter, extensive research progress has been made in investigating the pathophysiology of the disease, however, due to non availability of human retinal samples and also due to lack of proper animal model of DR, the exact molecular mechanism has not been elucidated, making therapeutic a difficult task. Therefore, research using large diabetic animal models which develop clinical signs of retinopathy are needed which may provide a correlation of the systemic metabolic profiles and retinal pathology with human studies to better understand the exact molecules and pathway(s) involved in DR. In addition, neurodegeneration and loss of neuronal functions as early signs of DR have been detected which may implicate later in vascular pathology. Precise molecular studies are required towards understanding the neurovascular damage in DR. These insights would be helpful in better understanding of the biochemical and molecular changes especially early in the diabetic retina for effective therapies towards prevention and amelioration of DR.

\section{Acknowledgements}

Authors acknowledge funding from Dr Nasser Al-Rashid Research Chair in Ophthalmology, King Saud University, KACST (ARP 30-23) and Deanship of Scientific Research (RGP-VPP-052) for the research support.

\section{References}

[1] Abu El-Asrar AM, Struyf S, Kangave D, Geboes K, Van Damme J. Chemokines in proliferative diabetic retinopathy and proliferative vitreoretinopathy. Eur Cytokine Netw. 2006 Sep;17(3):155-65.

[2] Abu El-Asrar AM, Struyf S, Verbeke H, Van Damme J, Geboes K. Circulating bonemarrow-derived endothelial precursor cells contribute to neovascularization in diabetic epiretinal membranes. Acta Ophthalmol. 2011 May;89(3):222-8.

[3] Abu El-Asrar AM, Al-Mezaine HS, Ola MS. Pathophysiology and management of diabetic retinopathy. Expert Review of Ophthalmology, 2009, 4, 627-647.

[4] Adamiec-Mroczek J, Oficjalska-Młyńczak J, Misiuk-Hojło M. Proliferative diabetic retinopathy-The influence of diabetes control on the activation of the intraocular molecule system. Diabetes Res Clin Pract. 2009 Apr;84(1):46-50. 
[5] Adamiec-Mroczek J, Oficjalska-Młyńczak J, Misiuk-Hojło M. Roles of endothelin-1 and selected proinflammatory cytokines in the pathogenesis of proliferative diabetic retinopathy: Analysis of vitreous samples. Cytokine. 2010 Mar;49(3):269-74.

[6] Adamiec-Mroczek J, Oficjalska-Młyńczak J. Assessment of selected adhesion molecule and proinflammatory cytokine levels in the vitreous body of patients with type 2 diabetes--role of the inflammatory-immune process in the pathogenesis of proliferative diabetic retinopathy. Graefes Arch Clin Exp Ophthalmol. 2008 Dec;246(12):1665-70.

[7] Adamis AP, Berman AJ. Immunological mechanisms in the pathogenesis of diabetic retinopathy. Semin Immunopathol. 2008 Apr; 30(2):65-84.

[8] Adibhatla RM, Hatcher JF. Role of Lipids in Brain Injury and Diseases. Future Lipidol. 2007 Aug;2(4):403-422.

[9] Agarwal R. Anti-inflammatory effects of short-term pioglitazone therapy in men with advanced diabetic nephropathy. Am J Physiol Renal Physiol. 2006 Mar;290(3):F600-5.

[10] Aiello LP, Davis MD, Girach A, Kles KA, Milton RC, Sheetz MJ, Vignati L, Zhi XE, PKCDRS2 Group. Effect of ruboxistaurin on visual loss in patients with diabetic retinopathy. Ophthalmology. 2006 Dec;113(12):2221-30.

[11] Alikhani M, Roy S, Graves DT. FOXO1 plays an essential role in apoptosis of retinal pericytes. Mol Vis. 2010 Mar 10;16:408-15.

[12] Aljada A, Garg R, Ghanim H, Mohanty P, Hamouda W, Assian E, Dandona P. Nuclear factor-kappaB suppressive and inhibitor-kappaB stimulatory effects of troglitazone in obese patients with type 2 diabetes: evidence of an antiinflammatory action?. J Clin Endocrinol Metab. 2001 Jul;86(7):3250-6.

[13] Al-Shabrawey M, Rojas M, Sanders T, Behzadian A, El-Remessy A, Bartoli M, Parpia AK, Liou G, Caldwell RB. Role of NADPH oxidase in retinal vascular inflammation. Invest Ophthalmol Vis Sci. 2008 Jul;49(7):3239-44.

[14] Ansquer JC, Foucher C, Aubonnet P, Le Malicot K. Fibrates and microvascular complications in diabetes--insight from the FIELD study. Curr Pharm Des. 2009;15(5):537-52.

[15] Antonetti DA, Barber AJ, Bronson SK, Freeman WM, Gardner TW, Jefferson LS, Kester M, Kimball SR, Krady JK, LaNoue KF, Norbury CC, Quinn PG, Sandirasegarane L, Simpson IA; JDRF Diabetic Retinopathy Center Group. Diabetic retinopathy: seeing beyond glucose-induced microvascular disease. Diabetes. 2006 Sep;55(9):2401-11.

[16] Arimura N, Otsuka H, Yamakiri K, Sonoda Y, Nakao S, Noda Y, Hashiguchi T, Maruyama I, Sakamoto T. Vitreous mediators after intravitreal bevacizumab or triamcinolone acetonide in eyes with proliferative diabetic retinopathy. Ophthalmology. 2009 May;116(5):921-6.

[17] Avignon A, Sultan A. PKC-B inhibition: a new therapeutic approach for diabetic complications?. Diabetes Metab. 2006 Jun;32(3):205-13.

[18] Azadi S, Johnson LE, Paquet-Durand F, Perez MT, Zhang Y, Ekström PA, van Veen T. $\mathrm{CNTF}+\mathrm{BDNF}$ treatment and neuroprotective pathways in the $\operatorname{rd} 1$ mouse retina. Brain Res. 2007 Jan 19;1129(1):116-29.

[19] Barba I, Garcia-Ramírez M, Hernández C, Alonso MA, Masmiquel L, García-Dorado D, Simó R. Metabolic fingerprints of proliferative diabetic retinopathy: an 1H-NMRbased metabonomic approach using vitreous humor. Invest Ophthalmol Vis Sci. 2010 Sep;51(9):4416-21. 
[20] Barber AJ, Lieth E, Khin SA, Antonetti DA, Buchanan AG, Gardner TW. Neural apoptosis in the retina during experimental and human diabetes. Early onset and effect of insulin. J Clin Invest. 1998;102(4):783-91.

[21] Barhwal K, Hota SK, Prasad D, Singh SB, Ilavazhagan G. Hypoxia-induced deactivation of NGF-mediated ERK1/2 signaling in hippocampal cells: neuroprotection by acetyl-L-carnitine. J Neurosci Res. 2008 Sep;86(12):2705-21.

[22] Bearse MA Jr, Han Y, Schneck ME, Barez S, Jacobsen C, Adams AJ. Local multifocal oscillatory potential abnormalities in diabetes and early diabetic retinopathy. Invest Ophthalmol Vis Sci. 2004;45(9):3259-65.

[23] Ben-Mahmud BM, Mann GE, Datti A, Orlacchio A, Kohner EM, Chibber R. Tumor necrosis factor-alpha in diabetic plasma increases the activity of core 2 GlcNAc-T and adherence of human leukocytes to retinal endothelial cells: significance of core 2 GlcNAc-T in diabetic retinopathy. Diabetes. 2004 Nov;53(11):2968-76.

[24] Bernardo A, Minghetti L. PPAR-gamma agonists as regulators of microglial activation and brain inflammation. Curr Pharm Des. 2006;12(1):93-109.

[25] Berry EM. Dietary fatty acids in the management of diabetes mellitus. Am J Clin Nutr. 1997 Oct;66(4 Suppl):991S-997S.

[26] Bertoni AG, Burke GL, Owusu JA, Carnethon MR, Vaidya D, Barr RG, Jenny NS, Ouyang P, Rotter JI. Inflammation and the incidence of type 2 diabetes: the MultiEthnic Study of Atherosclerosis (MESA). Diabetes Care. 2010 Apr;33(4):804-10.

[27] Bikfalvi A, Klein S, Pintucci G, Rifkin DB. Biological roles of fibroblast growth factor-2. Endocr Rev, 1997; 18: 26-45.

[28] Bloodworth JM Jr. Diabetic retinopathy. Diabetes. 1962;11:1-22.

[29] Brooks HL Jr, Caballero S Jr, Newell CK, Steinmetz RL, Watson D, Segal MS, Harrison JK, Scott EW, Grant MB. Vitreous levels of vascular endothelial growth factor and stromal-derived factor 1 in patients with diabetic retinopathy and cystoid macular edema before and after intraocular injection of triamcinolone. Arch Ophthalmol. 2004 Dec;122(12):1801-7.

[30] Brownlee M. Biochemistry and molecular cell biology of diabetic complications. Nature. 2001 Dec 13;414(6865):813-20.

[31] Brownlee M. The pathobiology of diabetic complications: a unifying mechanism. Diabetes. 2005 Jun;54(6):1615-25.

[32] Buse MG. Hexosamines, insulin resistance, and the complications of diabetes: current status. Am J Physiol Endocrinol Metab. 2006 Jan;290(1):E1-E8.

[33] Butler JM, Guthrie SM, Koc M, et al. SDF-1 is both necessary and sufficient to promote proliferative retinopathy. J Clin Invest. 2005 Jan;115(1):86-93.

[34] Chalam KV, Agarwal N, Agarwal R, Wordinger R, Vinjamaram S. Evaluation And Comparision Of Vitreal Ngf Levels In Human Proliferative Diabetic Retinopathy And Proliferative Vitreoretinopathy Invest Ophthalmol Vis Sci 2002;43: E-Abstract 1310.

[35] Chen P, Scicli GM, Guo M, Fenstermacher JD, Dahl D, Edwards PA, Scicli AG. Role of angiotensin II in retinal leukostasis in the diabetic rat. Exp Eye Res. 2006 Nov;83(5):1041-51.

[36] Chibber R, Ben-Mahmud BM, Chibber S, Kohner EM. Leukocytes in diabetic retinopathy. Curr Diabetes Rev. 2007 Feb;3(1):3-14. 
[37] Chung SS, Chung SK. Aldose reductase in diabetic microvascular complications. Curr Drug Targets. 2005 Jun;6(4):475-86.

[38] Chung SS, Ho EC, Lam KS, Chung SK. Contribution of polyol pathway to diabetesinduced oxidative stress. J Am Soc Nephrol. 2003 Aug;14(8 Suppl 3):S233-6.

[39] Connor KM, SanGiovanni JP, Lofqvist C, Aderman CM, Chen J, Higuchi A, Hong S, Pravda EA, Majchrzak S, Carper D, Hellstrom A, Kang JX, Chew EY, Salem N Jr, Serhan CN, Smith LE. Increased dietary intake of omega-3-polyunsaturated fatty acids reduces pathological retinal angiogenesis. Nat Med. 2007 Jul;13(7):868-73.

[40] Cotman CW. The role of neurotrophins in brain aging: aperspective in honor of Regino Perez-Polo. Neurochem Res, 2005, 30:877-881.

[41] Dagher Z, Park YS, Asnaghi V, Hoehn T, Gerhardinger C, Lorenzi M. Studies of rat and human retinas predict a role for the polyol pathway in human diabetic retinopathy. Diabetes. 2004 Sep;53(9):2404-11.

[42] Das Evcimen N, King GL The role of protein kinase C activation and the vascular complications of diabetes. Pharmacol Res. 2007 Jun;55(6):498-510.

[43] Davis MD, Sheetz MJ, Aiello LP, Milton RC, Danis RP, Zhi X, Girach A, Jimenez MC, Vignati L; PKC-DRS2 Study Group. Effect of ruboxistaurin on the visual acuity decline associated with long-standing diabetic macular edema. Invest Ophthalmol Vis Sci. 2009 Jan;50(1):1-4.

[44] Demircan N, Safran BG, Soylu M, Ozcan AA, Sizmaz S.Determination of vitreous interleukin-1 (IL-1) and tumour necrosis factor (TNF) levels in proliferative diabetic retinopathy. Eye. 2006 Dec;20(12):1366-9.

[45] Denis, U.; Lecomte, M.; Paget, C.; Ruggiero, D.; Wiernsperger, N. Lagarde, M. Advanced glycation end-products induce apoptosis of bovine retinal pericytes in culture: involvement of diacylglycerol/ceramide production and oxidative stress induction. Free Radic. Biol. Med, 2002, 33(2), 236-247.

[46] Derubertis FR, Craven PA. Activation of protein kinase C in glomerular cells in diabetes: mechanism and potential links to the pathogenesis of diabetic glomerulopathy. Diabetes. 1994;43:1-8.

[47] Diederen, R.M., La Heij, E.C., Deutz, N.E., 2006. Increased glutamate levels in the vitreous of patients with retinal detachment. Exp. Eye Res. 83, 45-50.

[48] Drel VR, Pacher P, Ali TK, Shin J, Julius U, El-Remessy AB, Obrosova IG. Aldose reductase inhibitor fidarestat counteracts diabetes-associated cataract formation, retinal oxidative-nitrosative stress, glial activation, and apoptosis. Int J Mol Med. 2008 Jun;21(6):667-76.

[49] Drel VR, Xu W, Zhang J, Kador PF, Ali TK, Shin J, Julius U, Slusher B, El-Remessy AB, Obrosova IG. Poly(ADP-ribose)polymerase inhibition counteracts cataract formation and early retinal changes in streptozotocin-diabetic rats. Invest Ophthalmol Vis Sci. 2009 Apr;50(4):1778-90.

[50] Du X, Matsumura T, Edelstein D, Rossetti L, Zsengeller Z, Szabo C, Brownlee M: Inhibition of GAPDH activity by poly(ADP-ribose) polymerase activates three major pathways of hyperglycemic damage in endothelial cells. J Clin Invest 112:1049-1057, 2003.

[51] Du XL, Edelstein D, Rossetti L, Fantus IG, Goldberg H, Ziyadeh F, Wu J, Brownlee M. Hyperglycemia-induced mitochondrial superoxide overproduction activates the 
hexosamine pathway and induces plasminogen activator inhibitor-1 expression by increasing Sp1 glycosylation. Proc Natl Acad Sci U S A. 2000 Oct 24;97(22):12222-6.

[52] Egami K, Murohara T, Shimada T, Sasaki K, Shintani S, Sugaya T, Ishii M, Akagi T, Ikeda $\mathrm{H}$, Matsuishi T, Imaizumi T. Role of host angiotensin II type 1 receptor in tumor angiogenesis and growth. J Clin Invest. 2003 Jul;112(1):67-75.

[53] Ehses JA, Lacraz G, Giroix MH, Schmidlin F, Coulaud J, Kassis N, Irminger JC, Kergoat M, Portha B, Homo-Delarche F, Donath MY. IL-1 antagonism reduces hyperglycemia and tissue inflammation in the type 2 diabetic GK rat. Proc Natl Acad Sci U S A. 2009 Aug 18;106(33):13998-4003.

[54] Feit-Leichman RA, Kinouchi R, Takeda M, Fan Z, Mohr S, Kern TS, Chen DF. Vascular damage in a mouse model of diabetic retinopathy: relation to neuronal and glial changes. Invest Ophthalmol Vis Sci. 2005 Nov;46(11):4281-7.

[55] Fletcher EL, Phipps JA, Ward MM, Puthussery T, Wilkinson-Berka JL. Neuronal and glial cell abnormality as predictors of progression of diabetic retinopathy. Curr Pharm Des. 2007;13(26):2699-712.

[56] Fort PE, Freeman WM, Losiewicz MK, Singh RS, Gardner TW. The retinal proteome in experimental diabetic retinopathy: up-regulation of crystallins and reversal by systemic and periocular insulin. Mol Cell Proteomics. 2009 Apr;8(4):767-79.

[57] Fox TE, Han X, Kelly S, Merrill AH 2nd, Martin RE, Anderson RE, Gardner TW, Kester M. Diabetes alters sphingolipid metabolism in the retina: a potential mechanism of cell death in diabetic retinopathy. Diabetes. 2006 Dec;55(12):3573-80.

[58] Fujinami A, Ohta K, Obayashi H, Fukui M, Hasegawa G, Nakamura N, Kozai H, Imai S, Ohta M Serum brain-derived neurotrophic factor in patients with type 2 diabetes mellitus: Relationship to glucose metabolism and biomarkers of insulin resistance. Clin Biochem. 2008 Jul;41(10-11):812-7.

[59] Gabbay KH. The sorbitol pathway and the complications of diabetes. $N$ Engl J Med. 1973;288:831-836.

[60] Gálvez MI. Rubosixtaurin and other PKC inhibitors in diabetic retinopathy and macular edema. Curr Diabetes Rev. 2009 Feb;5(1):14-7.

[61] Gao X, Belmadani S, Picchi A, Xu X, Potter BJ, Tewari-Singh N, Capobianco S, Chilian WM, Zhang C. Tumor necrosis factor-alpha induces endothelial dysfunction in Lepr(db) mice. Circulation. 2007 Jan 16;115(2):245-54.

[62] Gao X, Zhang H, Belmadani S, Wu J, Xu X, Elford H, Potter BJ, Zhang C. Role of TNFalpha-induced reactive oxygen species in endothelial dysfunction during reperfusion injury. Am J Physiol Heart Circ Physiol. 2008 (a) Dec;295(6):H2242-9.

[63] Gao X, Zhang H, Schmidt AM, Zhang C. AGE/RAGE produces endothelial dysfunction in coronary arterioles in type 2 diabetic mice. Am J Physiol Heart Circ Physiol. 2008 (b) Aug;295(2):H491-8.

[64] Geraldes P, Hiraoka-Yamamoto J, Matsumoto M, Clermont A, Leitges M, Marette A, Aiello LP, Kern TS, King GL. Activation of PKC-delta and SHP-1 by hyperglycemia causes vascular cell apoptosis and diabetic retinopathy. Nat Med. 2009;15:12981306.

[65] Geraldes P, King GL. Activation of protein kinase C isoforms and its impact on diabetic complications. Circ Res. 2010;106:1319-1331.

[66] Giacco F, Brownlee M. Oxidative stress and diabetic complications. Circ Res. 2010 Oct 29;107(9):1058-70. 
[67] Giovanni JP, Chew EY. The role of omega-3 long-chain polyunsaturated fatty acids in health and disease of the retina. Prog Retin Eye Res. 2005 Jan;24(1):87-138.

[68] Goh SY, Cooper ME. Clinical review: The role of advanced glycation end products in progression and complications of diabetes. J Clin Endocrinol Metab. 2008 Apr;93(4):1143-52.

[69] Goldin A, Beckman JA, Schmidt AM, Creager MA. Advanced glycation end products: sparking the development of diabetic vascular injury.Circulation. 2006 Aug 8;114(6):597-605.

[70] J, Bierhaus A, Nawroth P, Hannak D, Neumaier M, Bergfeld R, Giardino I, Brownlee M. Benfotiamine blocks three major pathways of hyperglycemic damage and prevents experimental diabetic retinopathy. Nat Med. 2003 Mar;9(3):294-9.

[71] Han Y, Adams AJ, Bearse MA Jr, Schneck ME. Multifocal electroretinogram and shortwavelength automated perimetry measures in diabetic eyes with little or no retinopathy. Arch Ophthalmol. 2004;122(12):1809-15.

[72] Harada C, Harada T, Quah HM, Maekawa F, Yoshida K, Ohno S, Wada K, Parada LF, Tanaka K. Potential role of glial cell line-derived neurotrophic factor receptors in Müller glial cells during light-induced retinal degeneration. Neuroscience. 2003;122(1):229-35.

[73] Harada T, Harada C, Mitamura Y, Akazawa C, Ohtsuka K, Ohno S, Takeuchi S, Wada K. Neurotrophic factor receptors in epiretinal membranes after human diabetic retinopathy. Diabetes Care. 2002 Jun;25(6):1060-5.

[74] Harvey S, Parker E, Macdonald I, Sanders EJ. Growth hormone is present in the human retina and vitreous fluid. Neurosci Lett. 2009 May 22;455(3):199-202.

[75] Hernández C, Segura RM, Fonollosa A, Carrasco E, Francisco G, Simó R. Interleukin-8, monocyte chemoattractant protein-1 and IL-10 in the vitreous fluid of patients with proliferative diabetic retinopathy. Diabet Med. 2005 Jun;22(6):719-22.

[76] Hong KH, Ryu J, Han KH. Monocyte chemoattractant protein-1-induced angiogenesis is mediated by vascular endothelial growth factor-A. Blood. 2005 Feb 15;105(4):14057.

[77] Hu FB, van Dam RM, Liu S. Diet and risk of Type II diabetes: the role of types of fat and carbohydrate. Diabetologia. 2001 Jul;44(7):805-17.

[78] Huang H, Gandhi JK, Zhong X, Wei Y, Gong J, Duh EJ, Vinores SA. TNF\{alpha\} Is Required for Late BRB Breakdown in Diabetic Retinopathy, and Its Inhibition Prevents Leukostasis and Protects Vessels and Neurons from Apoptosis. Invest Ophthalmol Vis Sci. 2011 Mar 10;52(3):1336-44.

[79] Hueber A, Wiedemann P, Esser P, Heimann K. Basic fibroblast growth factor mRNA, bFGF peptide and FGF receptor in epiretinal membranes of intraocular proliferative disorders (PVR and PDR). Int Ophthalmol 1996-97; 20: 345-50.

[80] Ido Y, Kilo C, Williamson JR. Cytosolic NADH/NAD+, free radicals, and vascular dysfunction in early diabetes mellitus. Diabetologia. 1997 Jul;40 Suppl 2:S115-7.

[81] Inagaki, Y.; Yamagishi, S.; Okamoto, T.; Takeuchi, M. ; Amano, S. Pigment epitheliumderived factor prevents advanced glycation end products-induced monocyte chemoattractant protein-1 production in microvascular endothelial cells by suppressing intracellular reactive oxygen species generation. Diabetologia, 2003, 46(2), 284-287. 
[82] Inoguchi T, Xia P, Kunisaki M, Higashi S, Feener EP, King GL. Insulin's effect on protein kinase $\mathrm{C}$ and diacylglycerol induced by diabetes and glucose in vascular tissues. Am J Physiol 1994;267:E369-79.

[83] Ishida S, Yamashiro K, Usui T, Kaji Y, Ogura Y, Hida T, Honda Y, Oguchi Y, Adamis AP. Leukocytes mediate retinal vascular remodeling during development and vaso-obliteration in disease. Nat Med. 2003 Jun;9(6):781-8.

[84] Ishida, S. ; Usui, T. ; Yamashiro, K.; Kaji, Y.; Ahmed, E.; Carrasquillo, K. G.; Amano, S.; Hida, T.; Oguchi, Y.; Adamis, A. P. VEGF164 is proinflammatory in the diabetic retina. Invest. Ophthalmol. Vis. Sci., 2003, 44(5), 2155-2162.

[85] Ismail-Beigi F, Craven T, Banerji MA, Basile J, Calles J, Cohen RM, Cuddihy R, Cushman WC, Genuth S, Grimm RH Jr, Hamilton BP, Hoogwerf B, Karl D, Katz L, Krikorian A, O'Connor P, Pop-Busui R, Schubart U, Simmons D, Taylor H, Thomas A, Weiss D, Hramiak I; ACCORD trial group. Effect of intensive treatment of hyperglycaemia on microvascular outcomes in type 2 diabetes: an analysis of the ACCORD randomised trial. Lancet. 2010 Aug 7;376(9739):419-30.

[86] Joussen AM, Poulaki V, Le ML, Koizumi K, Esser C, Janicki H, Schraermeyer U, Kociok N, Fauser S, Kirchhof B, Kern TS, Adamis AP. A central role for inflammation in the pathogenesis of diabetic retinopathy. FASEB J. 2004 Sep;18(12):1450-2.

[87] Joussen AM, Poulaki V, Qin W, Kirchhof B, Mitsiades N, Wiegand SJ, Rudge J, Yancopoulos GD, Adamis AP. Retinal vascular endothelial growth factor induces intercellular adhesion molecule-1 and endothelial nitric oxide synthase expression and initiates early diabetic retinal leukocyte adhesion in vivo. Am J Pathol. 2002 Feb;160(2):501-9.

[88] Kador PF, Randazzo J, Blessing K, Makita J, Zhang P, Yu K, Hosoya K, Terasaki T. Polyol formation in cell lines of rat retinal capillary pericytes and endothelial cells (TR-rPCT and TR-iBRB). J Ocul Pharmacol Ther. 2009 Aug;25(4):299-308.

[89] Kang Derwent JJ, Mieler WF. Thermoresponsive hydrogels as a new ocular drug delivery platform to the posterior segment of the eye. Trans Am Ophthalmol Soc. 2008;106:206-13; discussion 213-4.

[90] Kanwar M, Kowluru RA. Role of glyceraldehyde 3-phosphate dehydrogenase in the development and progression of diabetic retinopathy. Diabetes. 2009 Jan;58(1):22734.

[91] Kawashima M, Shoji J, Nakajima M, Kamura Y, Sato Y. Soluble IL-6 receptor in vitreous fluid of patients with proliferative diabetic retinopathy. Jpn J Ophthalmol. 2007 MarApr;51(2):100-4.

[92] Kern TS, Du Y, Miller CM, Hatala DA, Levin LA (2010) Overexpression of Bcl-2 in vascular endothelium inhibits the microvascular lesions of diabetic retinopathy. Am J Pathol 176:2550-2558.

[93] Kern TS, Miller CM, Du Y, Zheng L, Mohr S, Ball SL, Kim M, Jamison JA, Bingaman DP. Topical administration of nepafenac inhibits diabetes-induced retinal microvascular disease and underlying abnormalities of retinal metabolism and physiology. Diabetes. 2007 Feb;56(2):373-9.

[94] Kernie SG, Liebl DJ, Parada LF (2000) BDNF regulates eating behavior and locomotor activity in mice. EMBO J 19:1290-1300. 
[95] Kim JH, Kim JH, Lee YM, Ahn EM, Kim KW, Yu YS. Decursin inhibits VEGF-mediated inner blood-retinal barrier breakdown by suppression of VEGFR-2 activation. $J$ Cereb Blood Flow Metab. 2009 Sep;29(9):1559-67.

[96] Kowluru RA, Chan PS. Oxidative stress and diabetic retinopathy. Exp Diabetes Res. 2007;2007:43603.

[97] Koya D, Jirousek MR, Lin YW, Ishii H, Kuboki K, King GL. Characterization of protein kinase $\mathrm{C}$ beta isoform activation on the gene expression of transforming growth factor-beta, extracellular matrix components, and prostanoids in the glomeruli of diabetic rats. J Clin Invest.1997;100:115-126.

[98] Krabbe KS, Nielsen AR, Krogh-Madsen R, Plomgaard P, Rasmussen P, Erikstrup C, Fischer CP, Lindegaard B, Petersen AM, Taudorf S, Secher NH, Pilegaard H, Bruunsgaard H, Pedersen BK. Brain-derived neurotrophic factor (BDNF) and type 2 diabetes. Diabetologia. 2007 Feb;50(2):431-8. Epub 2006 Dec 7.

[99] Lassègue B, Clempus RE. Vascular NAD(P)H oxidases: specific features, expression, and regulation. Am J Physiol Regul Integr Comp Physiol. 2003 Aug;285(2):R277-97.

[100] Li J, Wang JJ, Chen D, Mott R, Yu Q, Ma JX, Zhang SX. Systemic administration of HMG-CoA reductase inhibitor protects the blood-retinal barrier and ameliorates retinal inflammation in type 2 diabetes. Exp Eye Res. 2009 Jun 15;89(1):71-8.

[101] Li Q, Puro DG. Diabetes-induced dysfunction of the glutamate transporter in retinal Müller cells. Invest Ophthalmol Vis Sci. 2002 Sep;43(9):3109-3116.

[102] Lieth E, Gardner TW, Barber AJ, Antonetti DA; Penn State Retina Research Group. Retinal neurodegeneration: early pathology in diabetes. Clin Experiment Ophthalmol. 2000;28(1):3-8.

[103] Liu J, Shi B, He S, Yao X, Willcox MD, Zhao Z. Changes to tear cytokines of type 2 diabetic patients with or without retinopathy. Mol Vis. 2010 Dec 31;16:2931-8.

[104] Lorenzi M. The polyol pathway as a mechanism for diabetic retinopathy: attractive, elusive and resilient. Exp Diabetes Res. 2007:61038.

[105] Madsen-Bouterse SA, Kowluru RA. Oxidative stress and diabetic retinopathy: pathophysiological mechanisms and treatment perspectives. Rev Endocr Metab Disord. 2008 Dec;9(4):315-27.

[106] Maier R, Weger M, Haller-Schober EM, El-Shabrawi Y, Wedrich A, Theisl A, Aigner R, Barth A, Haas A. Multiplex bead analysis of vitreous and serum concentrations of inflammatory and proangiogenic factors in diabetic patients. Mol Vis. 2008 Mar 27;14:637-43.

[107] Malchiodi-Albedi F, Matteucci A, Bernardo A, Minghetti L. PPAR-gamma, Microglial Cells, and Ocular Inflammation: New Venues for Potential Therapeutic Approaches. PPAR Res. 2008;2008:295784.

[108] Malhotra C. Proliferative diabetic retinopathy in acromegaly. Oman J Ophthalmol. 2010 May;3(2):96-7.

[109] Martin PM, Roon P, Van Ells TK, Ganapathy V, Smith SB. Death of retinal neurons in streptozotocin-induced diabetic mice. Invest Ophthalmol Vis Sci. 2004 Sep;45(9):3330-6.

[110] Mattson MP, Maudsley S, Martin B (2004) BDNF and 5-HT: adynamic duo in agerelated neuronal plasticity and neurodegen- erative disorders. Trends Neurosci 27:589-594. 
[111] Meyer-Franke A, Kaplan MR, Pfrieger FW, Barres BA. Characterization of the signaling interactions that promote the survival and growth of developing retinal ganglion cells in culture. Neuron. 1995 Oct;15(4):805-19.

[112] Min D, Xiao-Bo X, Si-Qi X. BDNF regulates GLAST and glutamine synthetase in mouse retinal Müller cells. J Cell Physiol. 2011 Mar 29. doi: 10.1002/jcp.22762. [Epub ahead of print]

[113] Misra GP, Singh RS, Aleman TS, Jacobson SG, Gardner TW, Lowe TL. Subconjunctivally implantable hydrogels with degradable and thermoresponsive properties for sustained release of insulin to the retina. Biomaterials. 2009 Nov;30(33):6541-7.

[114] Mo FM, Proia AD, Johnson WH, Cyr D, Lashkari K. Interferon gamma-inducible protein-10 (IP-10) and eotaxin as biomarkers in age-related macular degeneration. Invest Ophthalmol Vis Sci. 2010 Aug;51(8):4226-36.

[115] Mohr S, Xi X, Tang J, Kern TS. Caspase activation in retinas of diabetic and galactosemic mice and diabetic patients. Diabetes. 2002 Apr;51(4):1172-9.

[116] Mohr, S., Caspase-1/interleukin-1beta signaling in diabetic retinopathy. Acta Ophthalmologica. 2008, 86, S243.

[117] Molteni R, Fumagalli F, Magnaghi V, Roceri M, Gennarelli M, Racagni G, Melcangi RC, Riva MA. Modulation of fibroblast growth factor-2 by stress and corticosteroids: from developmental events to adult brain plasticity. Brain Res Brain Res Rev. 2001 Nov;37(1-3):249-58.

[118] Moore TC, Moore JE, Kaji Y, Frizzell N, Usui T, Poulaki V, Campbell IL, Stitt AW, Gardiner TA, Archer DB, Adamis AP. The role of advanced glycation end products in retinal microvascular leukostasis. Invest Ophthalmol Vis Sci. 2003 Oct;44(10):4457-64.

[119] Muranaka K, Yanagi Y, Tamaki Y, Usui T, Kubota N, Iriyama A, Terauchi Y, Kadowaki T, Araie M. Effects of peroxisome proliferator-activated receptor gamma and its ligand on blood-retinal barrier in a streptozotocin-induced diabetic model. Invest Ophthalmol Vis Sci. 2006 Oct;47(10):4547-52.

[120] Murata T, He S, Hangai M, Ishibashi T, Xi XP, Kim S, Hsueh WA, Ryan SJ, Law RE, Hinton DR. Peroxisome proliferator-activated receptor-gamma ligands inhibit choroidal neovascularization. Invest Ophthalmol Vis Sci. 2000 Jul;41(8):2309-17.

[121] Murugeswari P, Shukla D, Rajendran A, Kim R, Namperumalsamy P, Muthukkaruppan V. Proinflammatory cytokines and angiogenic and antiangiogenic factors in vitreous of patients with proliferative diabetic retinopathy and eales' disease. Retina. 2008 Jun;28(6):817-24.

[122] Myśliwiec M, Myśliwska J, Zorena K, Balcerska A, Malinowska E, Wiśniewski P.Interleukin $6-174(\mathrm{G}>\mathrm{C})$ gene polymorphism is related to celiac disease and autoimmune thyroiditis coincidence in diabetes type 1 children. Diabetes Res Clin Pract. 2008 Oct;82(1):108-12.

[123] Nagai N, Izumi-Nagai K, Oike Y, Koto T, Satofuka S, Ozawa Y, Yamashiro K, Inoue M, Tsubota K, Umezawa K, Ishida S. Suppression of diabetes-induced retinal inflammation by blocking the angiotensin II type 1 receptor or its downstream nuclear factor-kappaB pathway. Invest Ophthalmol Vis Sci. 2007 Sep;48(9):4342-50.

[124] Nagai N, Noda K, Urano T, Kubota Y, Shinoda H, Koto T, Shinoda K, Inoue M, Shiomi T, Ikeda E, Tsubota K, Suda T, Oike Y, Ishida S. Selective suppression of pathologic, 
but not physiologic, retinal neovascularization by blocking the angiotensin II type 1 receptor. Invest Ophthalmol Vis Sci. 2005 Mar;46(3):1078-84.

[125] Nagao K, Yanagita T. Bioactive lipids in metabolic syndrome. Prog Lipid Res. 2008 Mar;47(2):127-46.

[126] Nakae M, Kamiya H, Naruse K, Horio N, Ito $Y$, Mizubayashi R, Hamada Y, Nakashima E, Akiyama N, Kobayashi Y, Watarai A, Kimura N, Horiguchi M, Tabata Y, Oiso Y, Nakamura J. Effects of basic fibroblast growth factor on experimental diabetic neuropathy in rats. Diabetes. 2006 May;55(5):1470-7.

[127] Nakamura M, Barber AJ, Antonetti DA, LaNoue KF, Robinson KA, Buse MG, Gardner TW. Excessive hexosamines block the neuroprotective effect of insulin and induce apoptosis in retinal neurons. J Biol Chem. 2001 Nov 23;276(47):43748-55.

[128] Nerlich AG, Sauer U, Kolm-Litty V, Wagner E, Koch M, Schleicher ED. Expression of glutamine:fructose-6-phosphate amidotransferase in human tissues: evidence for high variability and distinct regulation in diabetes. Diabetes. 1998 Feb;47(2):170-8.

[129] Ning X, Baoyu Q, Yuzhen L, Shuli S, Reed E, Li QQ. Neuro-optic cell apoptosis and microangiopathy in KKAY mouse retina. Int J Mol Med. 2004 Jan;13(1):87-92.

[130] Noma H, Funatsu H, Mimura T, Harino S, Hori S. Aqueous humor levels of vasoactive molecules correlate with vitreous levels and macular edema in central retinal vein occlusion. Eur J Ophthalmol. 2010 Mar-Apr;20(2):402-9.

[131] Noma H, Funatsu H, Mimura T, Harino S, Hori S. Vitreous levels of interleukin-6 and vascular endothelial growth factor in macular edema with central retinal vein occlusion. Ophthalmology. 2009 Jan;116(1):87-93.

[132] Obrosova IG, Kador PF. Aldose reductase/polyol inhibitors for diabetic retinopathy. Curr Pharm Biotechnol. 2011 Mar 1;12 (3):373-85.

[133] Obrosova IG, Minchenko AG, Vasupuram R, White L, Abatan OI, Kumagai AK, Frank RN, Stevens MJ. Aldose reductase inhibitor fidarestat prevents retinal oxidative stress and vascular endothelial growth factor overexpression in streptozotocindiabetic rats. Diabetes. 2003 Mar;52(3):864-71.

[134] Obrosova IG, Pacher P, Szabó C, Zsengeller Z, Hirooka H, Stevens MJ, Yorek MA. Aldose reductase inhibition counteracts oxidative-nitrosative stress and poly(ADPribose) polymerase activation in tissue sites for diabetes complications. Diabetes. 2005 Jan;54(1):234-42.

[135] Obrosova IG, Stevens MJ, Lang HJ. Diabetes-induced changes in retinal NAD-redox status: pharmacological modulation and implications for pathogenesis of diabetic retinopathy. Pharmacology. 2001;62(3):172-80.

[136] Ola MS, Berkich DA, Xu Y, King MT, Gardner TW, Simpson I, LaNoue KF. Analysis of glucose metabolism in diabetic rat retinas. Am J Physiol Endocrinol Metab. 2006 Jun;290(6):E1057-67.

[137] Ola MS, Hosoya KI, Lanoue KF. Regulation of glutamate metabolism by hydrocortisone and branched chain keto acids in cultured rat retinal Müller cells (TR-MUL). Neurochem Int. 2011 Jul 3. [Epub ahead of print]

[138] Ono M, Ichihara J, Nonomura T et al (1997) Brain-derived neurrophic factor reduces blood glucose level in obese diabetic mice but not in normal mice. Biochem Biophys Res Commun 238:633-637. 
[139] Otani A, Takagi H, Oh H, Koyama S, Honda Y. Angiotensin II induces expression of the Tie2 receptor ligand, angiopoietin-2, in bovine retinal endothelial cells. Diabetes. 2001 Apr;50(4):867-75.

[140] Park SH, Park JW, Park SJ, Kim KY, Chung JW, Chun MH, Oh SJ. Apoptotic death of photoreceptors in the streptozotocin-induced diabetic rat retina. Diabetologia. 2003 Sep;46(9):1260-8.

[141] Patel A, MacMahon S, Chalmers J, Neal B, Billot L, Woodward M, Marre M, Cooper M, Glasziou P, Grobbee D, Hamet P, Harrap S, Heller S, Liu L, Mancia G, Mogensen CE, Pan C, Poulter N, Rodgers A, Williams B, Bompoint S, de Galan BE, Joshi R, Travert F \& ADVANCE Collaborative Group. Intensive blood glucose control and vascular outcomes in patients with type 2 diabetes. N Engl J Med. 2008 Jun 12;358(24):2560-2572.

[142] Pazdro R, Burgess JR. The role of vitamin E and oxidative stress in diabetes complications. Mech Ageing Dev. 2010 Apr;131(4):276-86.

[143] Peng PH, Lin HS, Lin S. Nerve fibre layer thinning in patients with preclinical retinopathy. Can J Ophthalmol. 2009 Aug;44(4):417-22.

[144] Petrovič MG, Korošec P, Košnik M, Hawlina M. Association of preoperative vitreous IL-8 and VEGF levels with visual acuity after vitrectomy in proliferative diabetic retinopathy. Acta Ophthalmol. 2010 Dec;88(8):e311-6.

[145] Petrovic MG, Korosec P, Kosnik M, Hawlina M. Vitreous levels of interleukin-8 in patients with proliferative diabetic retinopathy. Am J Ophthalmol. 2007 Jan;143(1):175-6.

[146] Podestà F, Romeo G, Liu WH, Krajewski S, Reed JC, Gerhardinger C, Lorenzi M. Bax is increased in the retina of diabetic subjects and is associated with pericyte apoptosis in vivo and in vitro. Am J Pathol. 2000 Mar;156(3):1025-32.

[147] Rahman I. Oxidative stress, transcription factors and chromatin remodelling in lung inflammation. Biochem Pharmacol. 2002 Sep;64(5-6):935-42.

[148] Reiter CE, Wu X, Sandirasegarane L, Nakamura M, Gilbert KA, Singh RS, Fort PE, Antonetti DA, Gardner TW. Diabetes reduces basal retinal insulin receptor signaling: reversal with systemic and local insulin. Diabetes 2006; 55:1148-56.

[149] Rodriguez-Fontal M, Kerrison JB, Alfaro DV, Jablon EP.Metabolic control and diabetic retinopathy. Curr Diabetes Rev. 2009 Feb;5(1):3-7.

[150] Ruperez M, Lorenzo O, Blanco-Colio LM, Esteban V, Egido J, Ruiz-Ortega M. Connective tissue growth factor is a mediator of angiotensin II-induced fibrosis. Circulation, 2003108, 1499-1505.

[151] Sato H, Sato S, Kawasaki AR, Yamamoto AT, Yamashita, BT Yamashita H. A Retinal Cell Damage Due to Oxidative Stress in Diabetic Retinopathy. Invest Ophthalmol Vis Sci 2005;46: E-Abstract 443.

[152] Sato T, Kusaka S, Shimojo H, Fujikado T. Simultaneous analyses of vitreous levels of 27 cytokines in eyes with retinopathy of prematurity. Ophthalmology. 2009 Nov;116(11):2165-9.

[153] Satofuka S, Ichihara A, Nagai N, Noda K, Ozawa Y, Fukamizu A, Tsubota K, Itoh H, Oike $Y$, Ishida S. (Pro)renin receptor-mediated signal transduction and tissue reninangiotensin system contribute to diabetes-induced retinal inflammation. Diabetes. 2009 Jul;58(7):1625-33. 
[154] Schallenberg M, Charalambous P, Thanos S. GM-CSF regulates the ERK1/2 pathways and protects injured retinal ganglion cells from induced death. Exp Eye Res. 2009 Nov; 89(5):665-77.

[155] Serrarbassa PD, Dias AF, Vieira MF. New concepts on diabetic retinopathy: neural versus vascular damage. Arq Bras Oftalmol. 2008 May-Jun;71(3):459-63.

[156] Sheikpranbabu S, Haribalaganesh R, Lee KJ, Gurunathan S. Pigment epitheliumderived factor inhibits advanced glycation end products-induced retinal vascular permeability. Biochimie. 2010 (a), 92(8):1040-51.

[157] Sheikpranbabu S, Ravinarayanan H, Elayappan B, Jongsun P, Gurunathan S. Pigment epithelium-derived factor inhibits vascular endothelial growth factor-and interleukin-1beta-induced vascular permeability and angiogenesis in retinal endothelial cells. Vascul Pharmacol. 2010 (b), 52(1-2):84-94.

[158] Sivalingam A, Kenney J, Brown GC, Benson WE, Donoso L. Basic fibroblast growth factor levels in the vitreous of patients with proliferative diabetic retinopathy. Arch Ophthalmol 1990; 108:869-72.

[159] Smith LE, Kopchick JJ, Chen W, Knapp J, Kinose F, Daley D, Foley E, Smith RG, Schaeffer JM. Essential role of growth hormone in ischemia-induced retinal neovascularization. Science. 1997 Jun 13;276(5319):1706-9.

[160] Sonmez K, Drenser KA, Capone A Jr, Trese MT. Vitreous levels of stromal cell-derived factor 1 and vascular endothelial growth factor in patients with retinopathy of prematurity. Ophthalmology. 2008 Jun;115(6):1065-1070.

[161] Sonta T, Inoguchi T, Tsubouchi H, Sekiguchi N, Kobayashi K, Matsumoto S, Utsumi $\mathrm{H}$, and Nawata $\mathrm{H}$. Evidence for contribution of vascular $\mathrm{NAD}(\mathrm{P}) \mathrm{H}$ oxidase to increased oxidative stress in animal models of diabetes and obesity. Free Radic Biol Med 37: 115-123, 2004.

[162] Stitt AW 2001 Advanced glycation: an important pathological event in diabetic and age related ocular disease. Br J Ophthalmol 85:746-753.

[163] Stitt AW, Bhaduri T, McMullen CB, Gardiner TA, Archer DB. Advanced glycation end products induce blood-retinal barrier dysfunction in normoglycemic rats. Mol Cell Biol Res Commun. 2000 Jun;3(6):380-8.

[164] Susnow N, Zeng L, Margineantu D, Hockenbery DM (2009) Bcl-2 family proteins as regulators of oxidative stress. Semin Cancer Biol 9:42-49.

[165] Suzuki, Y., Ruiz-Ortega, M., Lorenzo, O., Ruperez, M., Esteban, V., \& Egido, J. (2003). Inflammation and angiotensin II. Int. J. Biochem. Cell Biol., 35, 881-900.

[166] Tadayoni R, Paques M, Gaudric A, Vicaut E. Erythrocyte and leukocyte dynamics in the retinal capillaries of diabetic mice. Exp Eye Res. 2003 Oct;77(4):497-504.

[167] Tamura H, Miyamoto K, Kiryu J, Miyahara S, Katsuta H, Hirose F, Musashi K, Yoshimura N. Intravitreal injection of corticosteroid attenuates leukostasis and vascular leakage in experimental diabetic retina. Invest Ophthalmol Vis Sci. 2005 Apr;46(4):1440-4.

[168] Tawfik A, Sanders T, Kahook K, Akeel S, Elmarakby A, Al-Shabrawey M. Suppression of retinal peroxisome proliferator-activated receptor gamma in experimental diabetes and oxygen-induced retinopathy: role of NADPH oxidase. Invest Ophthalmol Vis Sci. 2009 Feb;50(2):878-84.

[169] The Diabetes Control and Complications Trial/Epidemiology of Diabetes Interventions and Complications ResearchGroup. Retinopathy and nephropathy in 
patients with type 1 diabetes four years after a trial of intensive therapy. $N$ Engl J Med 2000; 342:381-9.

[170] The relationship of glycemic exposure (HbA1c) to the risk of development and progression of retinopathy in the diabetes control and complications trial. Diabetes 1995; 44:968-83.

[171] Tombran-Tink J, Barnstable CJ. PEDF: a multifaceted neurotrophic factor. Nat Rev Neurosci 2003;4:628-36.

[172] van Dijk HW, Kok PH, Garvin M, Sonka M, Devries JH, Michels RP, van Velthoven $\mathrm{ME}$, Schlingemann RO, Verbraak FD, Abràmoff MD. Selective loss of inner retinal layer thickness in type 1 diabetic patients with minimal diabetic retinopathy. Invest Ophthalmol Vis Sci. 2009 Jul;50(7):3404-9.

[173] van Dijk HW, Verbraak FD, Kok PH, Garvin MK, Sonka M, Lee K, Devries JH, Michels $\mathrm{RP}$, van Velthoven ME, Schlingemann RO, Abràmoff MD. Decreased retinal ganglion cell layer thickness in patients with type 1 diabetes. Invest Ophthalmol Vis Sci. 2010 Jul;51(7):3660-5.

[174] van Leiden HA, Dekker JM, Moll AC, Nijpels G, Heine RJ, Bouter LM, Stehouwer CD, Polak BC. Blood pressure, lipids, and obesity are associated with retinopathy: the hoorn study. Diabetes Care. 2002 Aug;25(8):1320-5.

[175] Vincent JA, Mohr S. Inhibition of caspase-1/interleukin-1beta signaling prevents degeneration of retinal capillaries in diabetes and galactosemia. Diabetes. 2007 Jan;56(1):224-30.

[176] Whitmire W, Al-Gayyar MM, Abdelsaid M, Yousufzai BK, El-Remessy AB. Alteration of growth factors and neuronal death in diabetic retinopathy: what we have learned so far. Mol Vis. 2011 Jan 28;17:300-8.

[177] Wilkinson-Berka JL, Miller AG. Update on the treatment of diabetic retinopathy. ScientificWorldJournal. 2008 Feb 6;8:98-120.

[178] Wolter JR. Diabetic retinopathy. Am J Ophthalmol. 1961;51:1123-41.

[179] Wong CG, Rich KA, Liaw LH, Hsu HT, Berns MW. Intravitreal VEGF and bFGF produce florid retinal neovascularization and hemorrhage in the rabbit. Curr Eye Res 2001; 22: 140-7.

[180] Yamagishi S, Amano S, Inagaki Y, Okamoto T, Koga K, Sasaki N, Yamamoto H, Takeuchi M, Makita Z. Advanced glycation end products-induced apoptosis and overexpression of vascular endothelial growth factor in bovine retinal pericytes. Biochem Biophys Res Commun. 2002 Jan 25;290(3):973-8.

[181] Yamagishi S, Matsui T, Nakamura K, Takeuchi M, Imaizumi T. Pigment epitheliumderived factor (PEDF) prevents diabetes- or advanced glycation end products (AGE)-elicited retinal leukostasis. Microvasc Res. 2006 Jul-Sep;72(1-2):86-90.

[182] Yamagishi S, Matsui T, Nakamura K, Ueda S, Noda Y, Imaizumi T. Pigment epithelium derived factor (PEDF): its potential therapeutic implication in diabetic vascular complications. Curr Drug Targets 2008;9:1025-9.

[183] Yamagishi S, Matsui T, Nakamura K, Yoshida T, Takeuchi M, Inoue H, Yoshida Y, Imaizumi T. Pigment-epithelium-derived factor suppresses expression of receptor for advanced glycation end products in the eye of diabetic rats. Ophthalmic Res. 2007;39(2):92-7.

[184] Yamagishi S, Matsui T. Advanced glycation end products (AGEs), oxidative stress and diabetic retinopathy. Curr Pharm Biotechnol. 2011 Mar 1;12(3):362-8. 
[185] Yamagishi S. Advanced glycation end products and receptor-oxidative stress system in diabetic vascular complications. Ther Apher Dial. 2009 Dec;13(6):534-9.

[186] Yamagishi, S.; Matsui, T.; Nakamura, K.; Inoue, H.; Takeuchi, M.; Ueda, S.; Okuda, S. ; Imaizumi, T. Olmesartan blocks inflammatory reactions in endothelial cells evoked by advanced glycation end products by suppressing generation of reactive oxygen species. Ophthalmic. Res., 2007, 40(1), 10-15.

[187] Yamanaka M, Itakura Y, Ono-Kishino M, Tsuchida A, Nakagawa T, Taiji M. Intermittent administration of brain-derived neurotrophic factor (BDNF) ameliorates glucose metabolism and prevents pancreatic exhaustion in diabetic mice. J Biosci Bioeng. 2008 (a) Apr;105(4):395-402.

[188] Yamanaka M, Itakura Y, Tsuchida A, Nakagawa T, Taiji M.Brain-derived neurotrophic factor (BDNF) prevents the development of diabetes in prediabetic mice. Biomed Res. 2008 (b) Jun;29(3):147-53.

[189] Yanagi Y. Role of Peoxisome Proliferator Activator Receptor gamma on Blood Retinal Barrier Breakdown. PPAR Res. 2008;2008:679237.

[190] Yang SR, Chida AS, Bauter MR, Shafiq N, Seweryniak K, Maggirwar SB, Kilty I, Rahman I. Cigarette smoke induces proinflammatory cytokine release by activation of NF-kappaB and posttranslational modifications of histone deacetylase in macrophages. Am J Physiol Lung Cell Mol Physiol. 2006 Jul; 291(1):L46-57.

[191] Yki-Järvinen H, Daniels MC, Virkamäki A, Mäkimattila S, DeFronzo RA, McClain D. Increased glutamine:fructose-6-phosphate amidotransferase activity in skeletal muscle of patients with NIDDM. Diabetes. 1996 Mar;45(3):302-7.

[192] Yokoi M, Yamagishi S, Sato A et al. Positive association of pigment epithelium-derived factor (PEDF) with total anti-oxidant capacity in the vitreous fluid of patients with proliferative diabetic retinopathy. Br J Ophthalmol 2007;91:885-7.

[193] Yokoi M, Yamagishi SI, Takeuchi M, Ohgami K, Okamoto T, Saito W, Muramatsu M, Imaizumi T, Ohno S. Elevations of AGE and vascular endothelial growth factor with decreased total antioxidant status in the vitreous fluid of diabetic patients with retinopathy. Br J Ophthalmol. 2005 Jun;89(6):673-5.

[194] Yoshida A, Yoshida S, Khalil AK, Ishibashi T, Inomata H. Role of NF-kappaBmediated interleukin-8 expression in intraocular neovascularization. Invest Ophthalmol Vis Sci. 1998 Jun;39(7):1097-106.

[195] Yoshida S, Yoshida A, Ishibashi T, Elner SG, Elner VM. Role of MCP-1 and MIP-1alpha in retinal neovascularization during postischemic inflammation in a mouse model of retinal neovascularization. J Leukoc Biol. 2003 Jan;73(1):137-44.

[196] Yoshimura T, Sonoda KH, Sugahara M, Mochizuki Y, Enaida H, Oshima Y, Ueno A, Hata $\mathrm{Y}$, Yoshida H, Ishibashi T.Comprehensive analysis of inflammatory immune mediators in vitreoretinal diseases. PLoS One. 2009 Dec 4;4(12):e8158.

[197] Yu XH, Zhang H, Wang YH, Liu LJ, Teng Y, Liu P. Time-dependent reduction of glutamine synthetase in retina of diabetic rats. Exp Eye Res. 2009 Dec;89(6):967-71.

[198] Zhang X, Lassila M, Cooper ME, Cao Z. Retinal expression of vascular endothelial growth factor is mediated by angiotensin type 1 and type 2 receptors. Hypertension. 2004 Feb;43(2):276-81.

[199] Zheng L, Szabó C, Kern TS. Poly(ADP-ribose) polymerase is involved in the development of diabetic retinopathy via regulation of nuclear factor-kappaB. Diabetes. 2004 Nov;53(11):2960-7. 
[200] Ziaei M, Tennant M, Sanders EJ, Harvey S. Vitreous growth hormone and visual dysfunction. Neurosci Lett. 2009 Aug 21;460(1):87-91. 


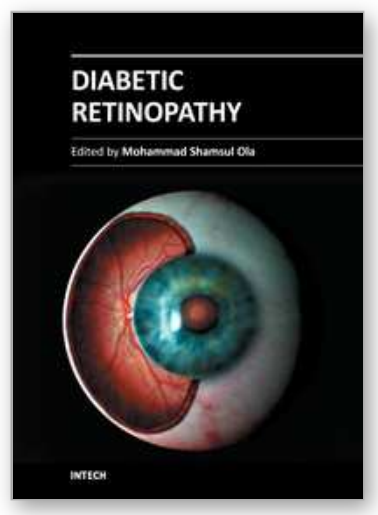

\author{
Diabetic Retinopathy \\ Edited by Dr. Mohammad Shamsul Ola
}

ISBN 978-953-51-0044-7

Hard cover, 356 pages

Publisher InTech

Published online 24, February, 2012

Published in print edition February, 2012

The aim of this book is to provide a comprehensive overview of current concepts in pathogenesis, diagnosis and treatments of diabetic retinopathy. It provides a collection of topics written by excellent authors, covering discussions on advances in understanding of pathophysiology, immunological factors and emerging concepts, relating to clinical aspects and treatment strategies. The contents of the book will not only provide a resource for our knowledge but also improve diagnosis and treatment options for those patients who suffer vision loss due to diabetic retinopathy.

\title{
How to reference
}

In order to correctly reference this scholarly work, feel free to copy and paste the following:

Mohammad Shamsul Ola and Mohd Imtiaz Nawaz (2012). Cellular and Molecular Mechanism of Diabetic Retinopathy, Diabetic Retinopathy, Dr. Mohammad Shamsul Ola (Ed.), ISBN: 978-953-51-0044-7, InTech, Available from: http://www.intechopen.com/books/diabetic-retinopathy/cellular-and-molecular-mechanism-ofdiabetic-retinopathy

\section{INTECH}

open science | open minds

\section{InTech Europe}

University Campus STeP Ri

Slavka Krautzeka 83/A

51000 Rijeka, Croatia

Phone: +385 (51) 770447

Fax: +385 (51) 686166

www.intechopen.com

\section{InTech China}

Unit 405, Office Block, Hotel Equatorial Shanghai

No.65, Yan An Road (West), Shanghai, 200040, China

中国上海市延安西路65号上海国际贵都大饭店办公楼 405 单元

Phone: +86-21-62489820

Fax: +86-21-62489821 
(C) 2012 The Author(s). Licensee IntechOpen. This is an open access article distributed under the terms of the Creative Commons Attribution 3.0 License, which permits unrestricted use, distribution, and reproduction in any medium, provided the original work is properly cited. 